\title{
MEDIA SIBER, APARAT, DAN PEMBERITAAN KEBERAGAMAN
}

\author{
Riris Loisa, Eko Harry Susanto, Ahmad Junaidi, dan Felicia Loekman \\ Universitas Tarumanagara Jakarta Jalan Letjen S. Parman Nomor 1 Jakarta 11470 \\ Telp 021-56960586 / Email: ririsl@fikom.untar.ac.id
}

\begin{abstract}
The up and down of relations between the government and the media have been the topic of various studies for decades. Historically, relations between the two parties were characterized by unequal power relations. Reform and development of digital communication technology gives hope for press freedom in producing and distributing information to the public free from government interference. This study aims to describe the relationship between cyber media and key informants, especially government officials in covering diversity issues. This research is based on research conducted with a normative theory perspective, applying a case study method for 2 (two) years, beginning with content analysis of 200 (two hundred) articles on diversity in cyber media, followed by discussions with 30 (thirty) media journalists cyber, 15 journalists in Jakarta, and 15 in Medan. In the second year, an electronic survey was conducted for cyber media journalists. The results of the study show that in reporting on the issue of diversity, cyber media actually makes government officials primary sources. This shows that the dynamics of cyber media relations and current government apparatus in terms of reporting on diversity issues are characterized by the closeness that was previously framed in power relations, currently in an urgent relationship of interest, accuracy, and risk management. The substance of this study provides input for journalists to be wiser in addressing technological advancements in various fields, especially cyber media.
\end{abstract}

Keywords: cyber media, government apparatus, diversity issues.

\begin{abstract}
Abstrak
Pasang-surut hubungan antara pemerintah dan media, telah menjadi topik berbagai penelitian selama beberapa dekade. Secara historis, hubungan antara kedua belah pihak diwarnai relasi kuasa yang tidak seimbang. Reformasi dan perkembangan teknologi komunikasi digital memberikan harapan akan kebebasan pers dalam memproduksi maupun mendistribusikan informasi kepada masyarakat yang terbebas dari campur tangan pemerintah. Penelitian ini bertujuan untuk menemukan gambaran relasi antara media siber dan narasumber utama, terutama aparat pemerintah dalam peliputan isu-isu keberagaman. Penelitian ini didasari penelitian yang dilakukan dengan perspektif teori normatif, menerapkan metode studi kasus selama 2 (dua) tahun, diawali analisis isi terhadap 200 (dua ratus) artikel mengenai keberagaman di dalam media siber, dilanjutkan dengan diskusi dengan 30 (tiga puluh) jurnalis media siber, 15 jurnalis di Jakarta, dan 15 di Medan. Pada tahun kedua, dilakukan survey elektronik kepada jurnalis media siber. Hasil penelitian memperlihatkan, bahwa dalam memberitakan isu keberagaman, media siber justru menjadikan aparat pemerintah sebagai narasumber primer. Hal ini memperlihatkan dinamika relasi media siber dan aparat pemerintah saat ini dalam hal pemberitaan isu keberagaman ditandai dengan kedekatan yang dahulu dibingkai dalam relasi kuasa, pada saat ini dalam relasi kepentingan yang mendesak, akurasi, dan pengelolaan risiko. Substansi penelitian ini memberi masukan bagi jurnalis agar lebih bijak dalam menyikapi kemajuan teknologi di berbagai bidang, khususnya media siber.
\end{abstract}

Kata kunci: media siber, aparat pemerintah, isu keberagaman.

\section{Pendahuluan}

Relasi antara media dan pemerintah terus berdinamika, termasuk di Indonesia. Masa orde baru, aktivitas pers Indonesia seolaholah terkurung dalam bingkai kekuasaan, pemberitaan yang dihasilkan berpusat pada pencapaian kinerja pemerintah. Riset dan diskusi publik mengenai relasi antara media dan pemerintah di kala itu berpusar pada tuntutan akan kemerdekaan pers dari pemerintah dalam aspek politik (Manan, 2018: 4). Pada era reformasi, pers diberi 
kebebasan secara bertanggung jawab dalam menghasilkan sebuah pemberitaan, artinya pers tetap harus bertanggung jawab akan kebenaran berita yang disampaikan kepada masyarakat. UU No. 40 Tahun 1999 Pasal 2 yang berbunyi: "Kemerdekaan pers adalah salah satu wujud kedaulatan rakyat yang berasaskan prinsip-prinsip demokrasi, keadilan, dan supremasi hukum.” (https://pwi. or.id/index.php/uu-kej), menambah semangat pers untuk menghasilkan berita secara objektif kepada masyarakat Indonesia.

Dinamika politik yang semakin kondusif, dibarengi dengan kemajuan teknologi membawa banyak perubahan pada kehidupan pers di Indonesia. Pers Indonesia bahkan dapat dikatakan memasuki euphoria dengan adanya kemajuan teknologi. Hal tersebut antara lain tercermin dari berbagai media online yang bermunculan di Indonesia. Data yang dikemukakan oleh Ketua Dewan Pers, Yosep Adi Prasetyo, pada peringatan Hari Pers Nasional pada tanggal 9 Februari 2018, menunjukkan bahwa Indonesia saat ini memiliki 47.000 media massa, 43.803 di antaranya adalah media daring (Antara, dalam Agustina (ed), Tempo.co, 2018).

Media pemberitaan siber seperti halnya media massa lain, melaporkan berbagai peristiwa yang terjadi kepada masyarakat. Keistimewaan media siber terletak pada teknologi pendukungnya yang memungkinkan pelaporan peristiwa kepada masyarakat dengan segera dan selalu mendapatkan informasi terbaru (Thorson \& Jackson, 2018). Semakin cepat berita diterbitkan berarti semakin cepat sebuah berita mengundang ' $k l i k$ ' dari masyarakat.
Perkembangan media siber, berjalan beriringan dengan menyeruaknya berbagai isu yang selama ini tidak banyak mendapat porsi di dalam media tradisional, antara lain isu keberagaman. Sementara kesadaran dan kepedulian masyarakat --termasuk di Indonesia-- terkait keberagaman sudah mulai meningkat, khususnya dalam konteks konstruksi sosial dan politik, baik dalam hal agama, etnis, suku dan ras (Behrens, 2006). Perkembangan media siber dan isu keberagaman merupakan isu yang belum banyak menjadi perhatian di dalam studi komunikasi.

Kode Etik Jurnalistik Pasal 5 berbunyi :

"Wartawan Indonesia menyajikan berita secara berimbang dan adil, mengutamakan kecermatan dari kecepatan serta tidak mencampuradukkan fakta dan opini sendiri. Karya jurnalistik berisi interprestasi dan opini wartawan, agar disajikan dengan menggunakan nama jelas penulisnya" (https://pwi.or.id/index.php/uu-kej).

Sesuai kode etik jurnalistik tersebut, maka berita yang diterbitkan harus merupakan hal yang merepresentasikan realitas dari beberapa sudut pandang secara sepadan, dengan memberikan kesempatan bagi berbagai pihak yang revelan. Dengan menjunjung nilai independen, sejatinya wartawan Indonesia tidak lagi mengandalkan narasumber tertentu sebagai sumber utama dalam sebuah pemberitaan melainkan melainkan langsung memastikannya dengan terjun ke lapangan, khususnya untuk dalam peliputan isuisu keberagaman yang adakalanya sensitif terhadap masyarakat.

Penelitian ini bertujuan untuk menemukan gambaran relasi antara media siber dan narasumber utama, terutama aparat pemerintah dalam peliputan isu- 
isu keberagaman. Melihat pasang-surut hubungan antara pemerintah dan media sejak era terdahulu serta kemajuan teknologi yang memberikan akses lebih luas kepada media siber di era globalisasi ini, mendorong rasa penasaran peneliti untuk melakukan penelitian lebih dalam mengenai hubungan antara media siber dan aparat pemerintah pada masa kini. Berdasarkan pertimbanganpertimbangan di atas, peneliti melakukan penelitian dengan rumusan masalah terkait bagaimana relasi media siber dan aparat dalam pemberitaan isu keberagaman.

\section{Metode Penelitian}

Penelitian ini dilakukan selama 2 (dua) tahun, dengan menerapkan metode studi kasus menggabungkan pendekatan kuantitatif dan kualitatif. Pendekatan kuantitatif ketika melakukan analisis sebagai perangkat sistematik yang memungkinkan untuk melakukan elaborasi konten yang termanisfestasi maupun laten pada seperangkat data dan satistik yang terstandarisasi, untuk menggambarkan pola dan perbandingan data (Jansen \& Laurie, 2016: 188-333). Di dalam penelitian ini analisis isi dilakukan terhadap 200 pemberitaan pada tahun 2017 di 4 (empat) media siber yang masuk dalam kategori 10 media siber paling banyak diakses pengguna internet versi Alexa.com.

Penelitian juga dilakukan melalui survei elektronik, untuk mendapatkan data dari khalayak yang lebih luas (Jensen \& Laurie, 2016: 141), selain itu survey ditujukan pula untuk melihat kecenderungan pemilihan narasumber utama dalam pemberitaan isu keberagaman para jurnalis dari media siber yang terdaftar di Dewan Pers pada tahun 2015, yang ketika itu berjumlah 68 media. Data yang diperoleh melalui survey diolah ke dalam bentuk statistik deskriptif untuk menggambarkan data dalam bentuk persentase frekuensi.

Sementara pendekatan kualitatif diterapkan di dalam upaya untuk mengelaborasi sudut pandang para jurnalis media siber secara lebih mendalam, pengumpulan data dilakukan melalui Focus Group Discussion (FGD). FGD dilakukan untuk mendapatkan informasi lebih dalam melalui penyingkapan para narasumber (Jensen \& Laurie, 2016: 188). Partisipan FGD pada penelitian ini adalah 30 jurnalis media siber yang ada di Jakarta dan Medan, di setiap kota diikuti oleh 15 jurnalis.

\section{Hasil Penelitian dan Pembahasan}

Narasumber utama merupakan faktor pentingdalamsebuah pemberitaan, pemilihan narasumber yang tepat memungkinkan untuk memberikan informasi yang bisa diandalkan (Ingram: 2012). Pemilihan narasumber menjadi lebih penting terlebih lagi ketika berita tersebut diterbitkan oleh media yang banyak diakses oleh pengguna media siber. Pemilihan narasumber utama harus benarbenar diperhatikan, karena akan berkaitan dengan akurasi sebuah berita. Penelitian ini memperlihatkan sebuah hasil yang cukup menarik terkait narasumber utama dalam sebuah pemberitaan isu keberagaman seperti yang digambarkan di dalam Grafik 1.

Sebagai salah satu isu sensitif, pemberitaan mengenai masalah keberagaman perlu kehati-hatian, khususnya dalam menetapkan narasumber yang akan menjadi 


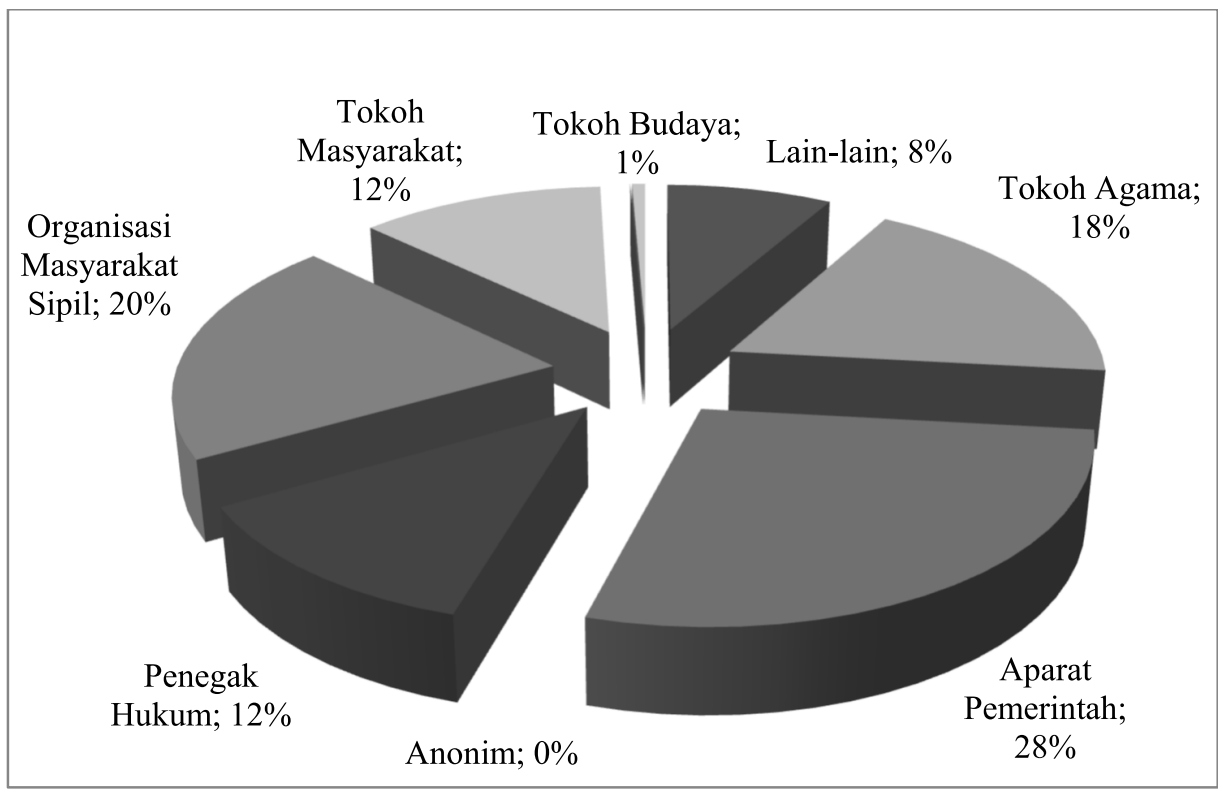

Grafik 1. Narasumber Utama Pemberitaan Isu Keberagaman di Media Siber $(\mathrm{n}=200)$

(Sumber: hasil olah data)

kunci dalam perolehan informasi. Grafik 1 memperlihatkan siapa yang sering dijadikan narasumber utama oleh media ketika mengunggah berita-berita keberagaman. Hal yang menarik, angka tertinggi narasumber yang terpilih adalah aparat pemerintah (28\%). Kenyataan ini mengindikasikan bahwa 4 (empat) media siber yang termasuk media paling banyak dibaca para pengguna internet, memercayai pemegang otoritas formal sebagai sumber informasi primer dalam pemberitaan isu keberagaman.

Hasil pengumpulan data seperti yang terlihat di dalam Grafik 1 menarik untuk dikaji lebih lanjut, mengingat bahwa hubungan antara aparat pemerintah dan media selama ini terbingkai di dalam relasi kuasa yang cenderung memuat keterpaksaan. Di masa yang lalu, media pers mencoba untuk melepaskan diri dari kendali pemerintah, namun hasil. Temuan ini menimbulkan tanda tanya, mengapa kebebasan akan akses informasi justru membawa media siber kembali kepada pemerintah, yang selama ini seakan ingin dijauhi.

\section{Rasionalisasi Pemilihan Aparat Pemerintah dari Perspektif Jurnalis}

Melalui focused group discussion dengan para jurnalis media siber, terungkap bahwa hal ini dilakukan demi kebutuhan untuk dapat menyediakan informasi segera yang akurat. Salah satu jurnalis media siber menjelaskan lebih rinci sebagai berikut:

"Kami mengakui bahwa pemerintah memang menjadi satu-satunya pemegang otoritas tertinggi di masyarakat. Jadi mau tidak mau, ketika kami mendapat laporan terjadi kejadian A di lokasi B, kami segera mengontak koresponden di kawasan tersebut untuk menghubungi instansi pemerintahan terkait. atau kami dari Jakarta langsung yang menghubungi pihak keamanan di daerah tersebut. Harus diakui, pernyataan dari otoritas yang berwenang adalah salah satu sumber resmi yang dipercaya masyarakat akan kebenarannya." (Narasumber Jurnalis Media Siber, dalam FGD di Jakarta, 2017)

Pernyataan serupa diungkapkan oleh jurnalis dari grup media siber lainnya, seperti yang terlihat dari pernyataan sebagai berikut: 
"Kami... berisi gabungan dari banyak media daerah yang awalnya berdiri sendiri, lalu kemudian dibeli... grup. Hal ini menyebabkan kami sering menyebut diri kami sebagai Indonesia Kecil. Banyak sekali isu-isu keberagaman yang muncul hampir di setiap daerah. Hampir semua media di bawah (grup) ini ingin melaporkan (isu keberagaman). Namun kebijakan tertinggi ada di Jakarta sebagai kantor pusat. Jika ada perintah, kami langsung cek ke lapangan, baik itu menghubungi otoritas yang berwenang atau ke lokasi terjadinya peristiwa." (Narasumber Jurnalis Media Siber, dalam FGD di Jakarta, 2017)

Penjelasan narasumber di atas setidaknya memperlihatkan bahwa pemilihan aparat pemerintah sebagai narasumber utama dilatarbelakangi suatu keyakinan bahwa instansi pemerintah merupakan "otoritas berwenang" dan sebagai "sumber resmi". Otoritas merupakan bentuk resmi dari kekuasaan untuk menjalankan suatu fungsi (https://kbbi.web.id). "Otoritas berwenang" dan sebagai "sumber resmi" oleh jurnalis dijadikan sebagai atribut dari sumber yang dapat dipercaya atau sumber yang akurat. Dalam pandangan umum, hal ini cukup masuk di akal. Namun jika dilihat secara historis, kekuasaan justru merupakan salah satu persinggungan disharmoni antara media dan pemerintah.

Melalui focus group discussion bersama para jurnalis media siber,juga terungkap bahwa dalam memberitakan isu keberagaman, hal pertama yang dilakukan adalah menghubungi aparat pemerintah melalui telepon. Hal tersebut dilakukan untuk segera mendapatkan informasi terbaru yang dinilai akurat, sehingga dapat segera pula diunggah ke dalam portal berita online tanpa perlu melakukan verifikasi terlebih dahulu ke lapangan, seperti yang diungkapkan narasumber jurnalis berikut ini:
"Media online memiliki karakter berbeda dengan media cetak. Salah satu karaksteristik utamanya adalah kecepatan dalam menyajikan berita..." (Narasumber Jurnalis Media Siber, dalam FGD di Jakarta, 2017)

Di dalam media berita digital, siklus produksi dan distribusi pesan merupakan suatu peluang sekaligus tantangan tersendiri. Selain memberi akses kepada berbagai sumber informasi yang hanya sejauh telepon genggam, teknologi digital memungkinkan percepatan di dalam siklus proses produksi dan distribusi pesan, tidak hanya di Indonesia, tren percepatan siklus ini terjadi di berbagai negara khususnya di Asia. Percepatan ini di satu sisi memungkinkan penyampaian pesan secara cepat kepada masyarakat, di sisi lain menggeser dunia pemberitaan menjadi sekedar fungsi pengumpul dan penyebar informasi dari pada penyaji berita yang berkualitas. (Chan, dalam Dragomir and Thompson, 2014).

Tuntutan untuk memberitakan perkembangan isu keberagaman dengan segera, dibayangiolehresikoatas dampakpemberitaan. Hal ini juga menjadi dasar pertimbangan di dalam pemilihan aparat pemerintah sebagai narasumber utama, hal ini terungkap dalam pernyataan narasumber FGD berikut ini:

"Karena untuk meminimalkan kerusuhan di masyarakat, jadi kami beritakan dari sumber resmi (pemerintah) dan pihak otoritas. Menghindari kericuhan di masyarakat karena pendapat dari pihak otoritas tidak se-emosional dari masyarakat" (Narasumber Jurnalis Media Siber, dalam FGD di Jakarta, 2017).

Dalam pemberitaan keberagaman, pemerintah diyakini sebagai peredam gejolak emosi yang dapat muncul dari narasumber masyarakat, aparat pemerintah dikaitkan dengan fungsi stabilitas 
masyarakat. Dalam hal ini terlihat bahwa melalui pemilihan narasumber aparat ketika memberitakan keberagaman, media siber berfungsi sebagai pemelihara status quo yang di sisi lain mengurangi efek perubahan sosial yang dapat dimunculkan oleh media (Mehraj, Bhat, dan Mehraj, 2014). Di sisi lain, hal ini memperlihatkan pengelolaan resiko yang diterapkan oleh media untuk menghindari berbagai kemungkinan yang dapat ditimbulkan oleh pemberitaanya.

Sebaran Pemilihan Aparat Pemerintah Sebagai Narasumber Utama

Hasil analisis isi dan Focused Group Discussion, selanjutnya mengundang pertanyaan, apakah pemilihan aparat pemerintah sebagai narasumber utama pemberitaan isu keberagaman hanya terjadi pada 4 (empat) media siber yang termasuk dalam 5 besar media siber yang paling banyak diakses oleh para pengguna internet, ataukah dilakukan juga oleh media sibermedia siber lainnya? Untuk mendapatkan jawaban mengenai hal ini, dilakukan survey elektronik terhadap 68 media siber yang terdaftar di dalam Data Pers Nasional 2015 dari Dewan Pers. Respon yang diterima dari survey elektronik berjumlah 67, berasal dari 11 provinsi di Indonesia, seperti yang terlihat di dalam grafik 2 :

Sebagai catatan, grafik 2 memperlihatkan persentase tertinggi responden berasal dari Kalimantan Barat. Hal ini tidak merepresentasikan besarnya jumlah jurnalis media siber di provinsi tersebut, tetapi semata-mata dikarenakan tinggi persentase pengembalian kuesioner dari provinsi tersebut.

Respon terhadap survei elektronik dari para jurnalis media siber di 11 (sebelas) provinsi tersebut dapat memberikan gambaran mengenai berbagai media siber, termasuk yang tidak terlalu banyak



Grafik 2. Domisili Responden Berdasarkan Provinsi $(n=67)$

(Sumber: Olah Data) 


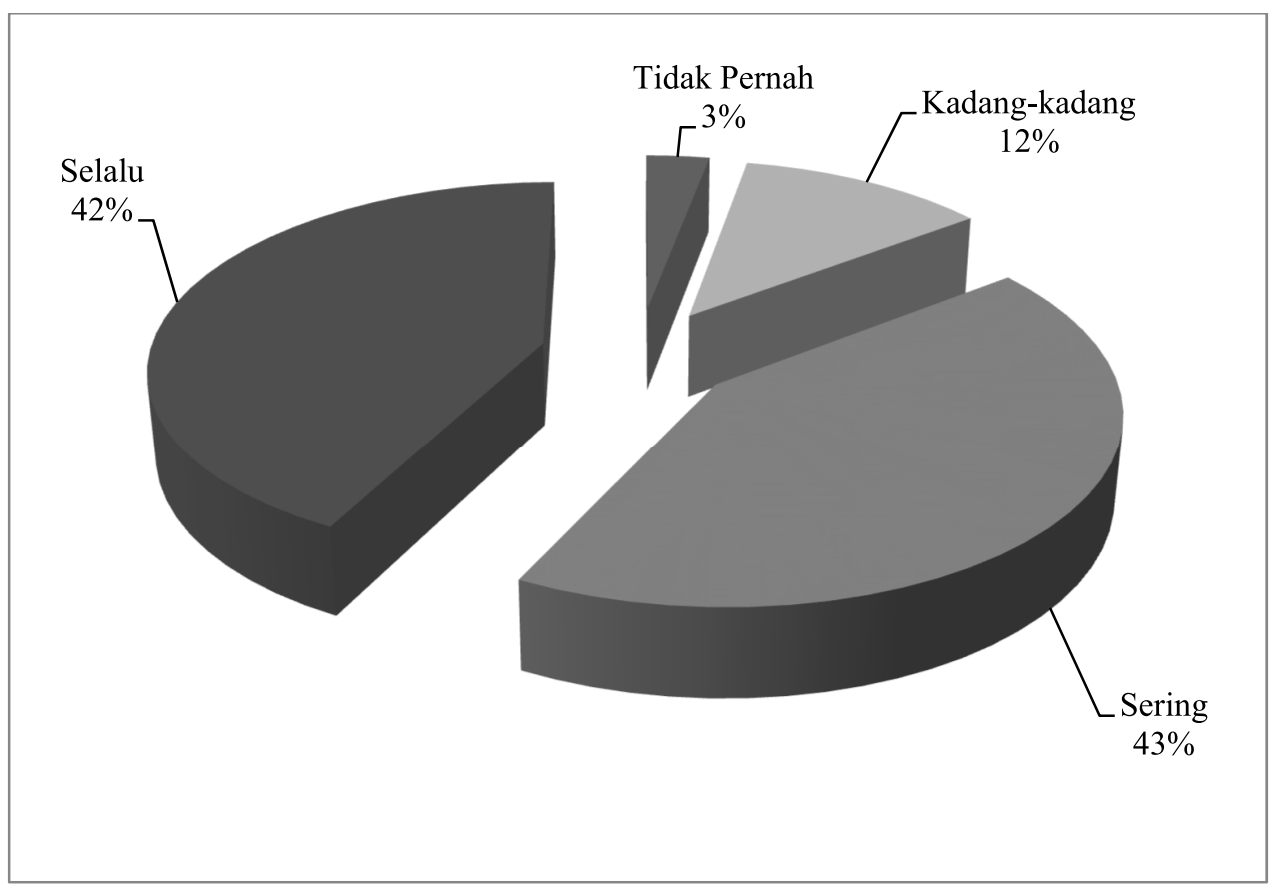

Grafik 3. Aparat Pemerintah sebagai Narasumber Utama $(\mathrm{n}=68)$

(Sumber: Olah Data)

diakses oleh pengguna internet. Grafik 3 memperlihatkan persentase pemilihan aparat pemerintah sebagai narasumber utama dari para responden.

Dari hasil olah data, terlihat bahwa persentase tertinggi, yaitu $43 \%$ jurnalis media siber di kesebelas provinsi di Indonesia sering memilih aparat pemerintah sebagai narasumber utama, sementara persentase tertinggi kedua, yaitu sebesar $42 \%$ selalu memilih aparat pemerintah sebagai narasumber utama. Hanya 12\% yang kadang-kadang, dan 3\% yang tidak pernah memilih aparat pemerintah sebagai narasumber utama.

Tingginya persentase "selalu" dan "sering" menjadikan aparat pemerintah sebagai narasumber utama, memperlihatkan bahwa kecenderungan ini tidak hanya terjadi pada media-media siber besar yang banyak diakses, tetapi juga pada media-media siber resmi lainnya yang ada di Indonesia. Hal ini memperkuat temuan penelitian bahwa dalam pemberitaan isu keberagaman, media siber cenderung menggunakan aparat pemerintah sebagai narasumber utama. Dengan demikian, terlihat juga bahwa di dalam memberitakan isu keberagaman, media siber cenderung menggambarkan realitas dari sudut pandang kekuasaan yang legitimate.

Ketika ditelusuri lebih lanjut, pemilihan aparat pemerintah sebagai narasumber sering dan selalu dilakukan oleh para jurnalis yang telah memiliki masa kerja lebih dari 16 (enam belas) tahun, dengan persentase masing-masing sebesar $11,8 \%$. Sementara jurnalis yang memiliki masa kerja selama 10 (sepuluh) sampai dengan 12 (dua belas) tahun, merupakan kelompok kedua yang sering memilih untuk menjadikan aparat pemerintah sebagai narasumber utama 
Tabel 1. Masa Kerja Jurnalis dan Pemilihan Aparat Pemerintah sebagai Narasumber Utama dalam Pemberitaan Isu Keberagaman Pada Saat Informasi Belum Memadai

$(\mathrm{n}=68)$

\section{Pemilihan Aparat Pemerintah Sebagai Narasumber Pertama}

\begin{tabular}{lccccc}
\multicolumn{1}{c}{ Masa Kerja } & Tidak Pernah & Kadang-kadang & Sering & Selalu & Total \\
\hline 1-3 tahun & $0,0 \%$ & $1,5 \%$ & $7,4 \%$ & $8,8 \%$ & $17,7 \%$ \\
$4-6$ tahun & $1,5 \%$ & $4,4 \%$ & $5,9 \%$ & $5,9 \%$ & $17,7 \%$ \\
$7-9$ tahun & $0,0 \%$ & $1,5 \%$ & $1,5 \%$ & $4,4 \%$ & $7,4 \%$ \\
$10-12$ tahun & $0,0 \%$ & $2,9 \%$ & $10,3 \%$ & $8,8 \%$ & $22,0 \%$ \\
$13-15$ tahun & $0,0 \%$ & $1,5 \%$ & $5,9 \%$ & $2,9 \%$ & $10,3 \%$ \\
$>16$ tahun & $1,5 \%$ & $0,0 \%$ & $11,8 \%$ & $11,8 \%$ & $25,1 \%$ \\
\hline Total & $\mathbf{3 , 0} \%$ & $\mathbf{1 1 , 8 \%}$ & $\mathbf{4 2 , 8 \%}$ & $\mathbf{4 2 , 6 \%}$ & $\mathbf{1 0 0 , 2 \%}$ \\
\hline
\end{tabular}

(Sumber: olah data)

pemberitaan isu keberagaman. Data ini menarik untuk dikaji, karena terlihat bahwa pemilihan narasumber pemerintah sering dan selalu dilakukan oleh para jurnalis senior. Hal ini dapat dilihat di dalam Tabel 1 tentang masa kerja jurnalis dan pemilihan narasumber utama.

\section{Relasi Media Siber dan Aparat Pemerintah sebagai Duet Elit?}

Seperti dikemukakan sebelumnya, salah satu kekuatan dari media siber adalah kesegeraan pemberitaan. Internet sebagai platform utama media siber, memungkinkan pembaharuan berita dari waktu ke waktu disajikan kepada pengguna internet selama 24 jam sehari. Kehadiran teknologi sedikit banyak telah membawa perubahan sikap dan perilaku wartawan, yang adakalanya terkesan pragmatis, lebih befokus pada tujuan, dan tanpa mengedepankan proses yaitu standar dan etika peliputan (Hidayat \& Anisti, 2015: 295).

Dalam hal pemberitaan keberagaman, yang oleh para jurnalis dikategorikan sebagai isu sensitif, tantangan untuk dapat memberitakan peristiwa secara cepat adalah bahwa narasumber yang dipilih sebagai sumber berita adalah orang-orang yang kompeten, dan memiliki otoritas atau kekuasaan yang terlegitimasi terkait peristiwa yang akan diliput. Pemilihan aparat pemerintah sebagai narasumber pertama setidaknya memperlihatkan kecenderungan media yang dalam memilih narasumber berita cenderung bersifat elit-sentris. Kecenderungan untuk memilih narasumber elit seperti ini sebetulnya banyak mendatangkan kritik terhadap media (Thorsen \& Jackson 2018: 847).

Realitas keberagaman yang disampaikan dari persepektif pemerintah merupakan persepsi yang telah melalui filter kepentingan kekuasaan, dan bukan merupakan realitas yang dialami secara langsung oleh orangorang yang terlibat di dalam peristiwa keberagaman itu sendiri. Sumber informasi seperti ini memperlihatkan bahwa di dalam memberitakan isu keberagaman, media siber kembali membangun jalur informasi yang bersifat satu arah dari narasumber elit kepada masyarakat. Sebagai realitas yang 
telah dipersepsi sesuai kepentingan elit kekuasaan.

Sementara media siber memilih narasumber elit, para jurnalis profesional sendiri acapkali dikategorikan sebagai kelompok elit demokrasi, berperan sebagai narasumber elit, yang berperan memberikan pencerahan, sebagai gate keepers yang menjalankan fungsi informasi bersifat topdown kepada masyarakat (Hermida, et.all., dalam Josephi, dalam Witschge, Anderson, Domingo \& Hermida, 2016: 14). Sebagai kelompok elit demokrasi, media memilih isu yang akan diberitakan kepada masyarakat atau tidak, serta memberi panduan tentang bagaimana memakainya.

Dengan demikian, terlihat indikasi bahwa relasi antara media siber dengan aparat pemerintah dalam pemberitaan isu keberagaman seolah-olah menempatkan keduanya pada posisi elit, pemerintah sebagai narasumber elit bagi jurnalis terkait kasus keberagaman, sementara media siber sebagai sumber informasi elit bagi masyarakat. Duet dua kelompok elit ini, menyebabkan realitas yang disajikan kepada masyarakat adalah yang telah tersaring oleh kepentingan, bukan lagi realitas murni. Hal ini dapat menyebabkan isu keberagaman yang diberitakan tidak lagi sebagai mana adanya seperti yang betul-betul terjadi dikarenakan interaksi dan pemaknaan orang-orang yang terlibat di dalam peristiwa keberagaman itu sendiri.

Mengingat bahwa kecepatan merupakan kata kunci sekaligus keistimewaan media siber, relasi antara media siber dengan aparat pemerintah sepertinya tidak terelakkan.
Kecepatan perkembangan informasi merupakan hal yang dianggap penting oleh jurnalis, adakalanya apa yang penting bagi masyarakat, ditentukan berdasarkan anggapan bahwa jurnalis memahami apa yang diharapkan oleh masyarakat (Rosen, Guenther \& Froehlich, 2016: 347).

Ketika memberitakan sudut pandang aparat, media siber menawarkan satu sudut pandang elit. Padahal, jika mengacu pada penggalan Pasal 5 Kode Etik Jurnalistik, "Wartawan Indonesia menyajikan berita secara berimbang dan adil, mengutamakan kecermatan dari kecepatan" tentunya hal ini menjadi suatu yang perlu dicermati lebih lanjut. Duet elit ini setidaknya mengindikasikan dua hal yang memerlukan penelitian lebih lanjut: (1) apakah pemilihan sudut pandang narasumber pemerintah memang mencerminkan apa yang memang dianggap penting oleh masyarakat, dalam ini kecepatan yang melampaui keberimbangan seperti tercantum di dalam Pasal 5 KEJ; dan (2) apakah justru kode etik jurnalistik yang perlu ditinjau kembali sejalan dengan perkembangan dunia pemberitaan berbasis internet yang mengedepankan kecepatan.

\section{Simpulan}

Penelitian ini menyimpulkan bahwa aparat pemerintah sering dan selalu menjadi narasumber utama dalam pemberitaan isu keberagaman di dalam media siber. Hal ini disebabkan karena kepentingan media siber dalam hal ini prioritas pada kecepatan dalam mengunggah suatu berita, pengakuan akan kekuasaan terlegitimasi pada pemerintah dan stabilitas masyarakat. Dalam hal isu keberagaman, aparat pemerintah saat ini 
dinilai sebagai sumber informasi yang akurat, dan memungkinkan media siber untuk melakukan pemberitaan dengan segera tanpa harus lebih dulu melakukan liputan ke lapangan dengan risiko yang kecil.

Dalam era sebelumnya, media mencoba untuk melepaskan diri dari kendali pemerintah, kini media kembali bergantung kepada aparat pemerintah sebagai narasumber utama, khususnya dalam pemberitaan isu keberagaman. Di satu sisi, hal ini lambat laun dapat kembali membangun subordinasi media terhadap pemerintah, yang kali ini dibangun oleh media siber secara sukarela. Di sisi lain, kondisi ini dapat memunculkan duet dua kelompok elit masyarakat, yaitu pemerintah sebagai narasumber elit bagi jurnalis terkait kasus keberagaman, sementara media siber merupakan sumber informasi elit bagi masyarakat.

Substansi penelitian ini berupa kebijakan dalam menyikapi kemajuan teknologi di berbagai bidang seharusnya mendorong jurnalis untuk semakin independen dan tidak mengandalkan pihak-pihak tertentu dalam suatu pemberitaan, melainkan melakukan peliputan di lapangan, verifikasi secara langsung, serta mewawancarai berbagai pihak terkait peristiwa yang diberitakan, sehingga dapat menyajikan fakta dari berbagai persepektif, dengan terverifikasi, dan menyeluruh.

\section{Daftar Pustaka}

Agustina, Widiarsi (ed). (2018) Terungkap, Indonesia Punya Media Massa Terbanyak di Dunia. Dalam TEMPO. CO Sabtu, 10 Februari 2018 05:25 WIB https://nasional.tempo.co/read/1059285/ terungkap-indonesia-punya-mediamassa-terbanyak-di-dunia

Dragomir, Marius and Mark Thompson (2014) Mapping Digital Media Global Findings, New York: Open Society Foundations. https://www.opensocietyfoundations. org/sites/default/files/mapping-digitalmedia-overviews-20140828.pdf

Hidayat, Dasrun \& Anisti (2015) Wartawan Media Now dalam Mengemas Berita: Perspektif Situational Theory, dalam Jurnal ASPIKOM Vol 2 No 5 http:// jurnalaspikom.org/index.php/aspikom/ article/view/81/77

Ingram, David (2012) The News Manual, Volume 3: Ethics \& The Law. NSW: UNESCO https://www.thenewsmanual. net/Manuals\%20 Volume\%203/ volume3_59.htm

Jansen, Eric Allen \& Charles Laurie, Doing Real Research A Practical Guide to Social Research (2016) London: Sage Publications Ltd

Josephi, Beate, Digital Journalism and Democracy dalam Witschge, C.W. Anderson, David Domingo and Alfred Hermida (2016) The Sage Handbook of Digital Journalism. London: Sage Publications Ltd.

Manan, Bagir (2018) Kemerdekaan Pers dan Etika Pers, dalam Berta Dewan Pers "ETIKA", (versi elektronik) Edisi Januari 2018. Jakarta: Dewan Pers

Mehraj, Hakim Khalid, Akhtar Neyaz Bhat, Hakeem Rameez Mehraj (2014) Impacts OF Media on Society: A Sociological Perspective. International Journal of Humanities and Social Science Invention ISSN (Online): 2319 - 7722, ISSN (Print): 2319 - 7714 www.ijhssi. org Volume 3 Issue 6, June. 2014. http:// www.ijhssi.org/papers/v3(6)/Version-4/ L0364056064.pdf 
Rosen, Cecilia, Lars Guenther \& Klara Froehlich (2016) The Question of Newsworthiness: A Cross-Comparison Among Science Journalists' Selection Criteria in Argentina, France and Germany dalam Scince Communication, Linking Theory and Practice Vol 38 Number 3 June 2016 323-355 Sage Publications DOI $10.1177 / 1075547016645585$

Thorsen, Einar \& Daniel Jackson (2018) Seven Characteristics Defining Online News Formats, Digital Journalism, 6:7, 847-868. UK Limited, trading as Taylor \& Francis Group. DOI: 10.1080/21670811.2018.1468722 https:// doi.org/10.1080/21670811.2018.1468722

Undang-Undang Republik IndonesiaNomor 40 Tahun 1999 Tentang Pers, dan Kode Etik Jurnalistik (Kej) Persatuan Wartawan Indonesia (PWI) https://pwi. or.id/index.php/uu-kej

Witschge, Tamara, C.W. Anderson, David Domingo and Alfred Hermida (eds) (2016) The Sage Handbook of Digital Journalism. London: Sage Publications Ltd. 